九州大学学術情報リポジトリ

Kyushu University Institutional Repository

\title{
Mucosal delivery of fish vaccines: Local and systemic immunity following mucosal immun isations
}

Somamoto, Tomonori

Laboratory of Marine Biochemistry, Department of Bioscience and Biotechnology, Graduate School of Bioresource and Bioenvironmental Sciences, Kyushu University

Nakanishi, Teruyuki

Goto Aquaculture Institute Co., Ltd

http://hdl. hand le. net/2324/2555029

出版情報: Fish and Shellfish Immunology. 99，pp.199-207，2020-04-01. Elsevier バージョン：

権利関係 : 
Mucosal delivery of fish vaccines: local and systemic immunity following mucosal immunisations

4

6

$7 \quad$ aaboratory of Marine Biochemistry, Department of Bioscience and Biotechnology,

8 Graduate School of Bioresource and Bioenvironmental Sciences, Kyushu University,

$9 \quad$ Kyushu University, Motooka 744, Fukuoka 819-0395, Japan

10

11

12 boto Aquaculture Institute Co., Ltd, Sayama city, Saitama 350-1332, Japan

13

*Corresponding author: Tomonori Somamoto

15 E-mail: somamoto@agr.kyushu-u.ac.jp

16 


\section{Abstract}

18 The mucosal organs of fishes are directly exposed to their aquatic environment, which is

19 suited to the colonization and growth of microorganisms, and thus these barriers are

20 considered to play an important role in maintaining homeostasis and preventing entry of

21 invasive pathogens. Research on fish mucosal immunity have shown that mucosal organs

22 such as gills, skin, intestines, and olfactory organs harbor lymphoid cells, including $\mathrm{T}$ and

23 B cells as well as dendritic-like cells. Findings related to immune responses following

24 direct administration of antigens into the mucosal organs could help to shed light upon

25 the development of fish mucosal vaccines. The present review highlights vaccine delivery

26 via mucosal organs, in particular focusing on methods other than those of typical mucosal

27 vaccine platforms, such as oral and immersion vaccines. In addition, we propose the

28 hypothesis that mucosal tissues are important sites for generating cell-mediated immunity

29 following vaccination with extracellular antigens.

30

31 Keywords: mucosal delivery, teleost, mucosa-associated lymphoid tissues, local and

32 systemic immunity, cell-mediated immunity, fin injection 
Mucosal vaccines employed for humans and animals include oral, nasal, sublingual and genital tract vaccines, which have many advantages when compared to systemic vaccines in terms of means of delivery and stimulation of the immune system [1]. Simple means of delivery which are needle-free administrations, results in low stress for vaccine recipients and administrators. In addition, these vaccines are capable of inducing both systemic and mucosal immune responses. Thus, mucosal vaccines are ideal from both practical and immunological aspects, and further progress of their development is warranted. Recently, studies have highlighted prospective vaccines and attempted to develop them against various pathogens, such as food vaccines mediating plants, bacteria (e.g. Lactobacillus and Bacillus), yeasts and algae [2], [3], buccal and sublingual vaccines employing orally disintegrating tablets or fast-dissolving films [4], [5], and nasal sprays [6].

Unlike terrestrial vertebrates, fish are constantly exposed to an aqueous environment, which is ideally suited for the spread of microorganisms. Diverse environmental habitats have created distinct anatomical and physiological differences between terrestrial mammals and fish species, and as a result the mucosal immunity of fishes is considered to be robust. Thus, mucosal immunity is currently a topic of great interest within fish immunology, with previous studies providing much evidence that fish possess mucosal immune systems distinct from those of mammals [7], [8]. According to the accumulated knowledge of fish mucosal immunity, vaccination via mucosal tissues would be expected to be a promising direction for teleost fish to efficiently induce adaptive immunity with long-term memory. This review describes possible vaccination routes for teleost fish along with their resulting local and systemic immune responses, and explores prospective 
methods in addition to the typical mucosal vaccine platforms, such as oral and immersion

58

59

60

61 vaccines.

\section{Fish mucosal organs}

The mucosa-associated lymphoid tissues (MALTs) of mammals are located within various mucosal sites, such as the gastrointestinal tract, oral passage, nasopharyngeal tract, thyroid, breast, lung, salivary glands, eye, and skin, and as secondary lymphoid organs are known to be one of the important sites for generation and maturation of adaptive immune cells. In teleost fish, the mucosal organs such as the gills, intestine, skin and olfactory organs are populated by lymphoid cells, including $\mathrm{T}$ and $\mathrm{B}$ cells as well as dendritic-like cells. While in fish organized lymphoid structures such as Peyer's patches and tonsils have not been found within skin, intestine or olfactory organ, diffuse lymphoid cells are present in these organs. Only gills contain organized lymphoid structure within their mucosal tissues from Atlantic salmon [9]. Although the diffuse or organized lymphoid cells distributed within fish mucosal organs cannot be regarded as counterparts of mammalian MALTs due to the physiological differences between mammals and fish, studies on fish mucosal immunity have shown that these organs share functional similarities to mammalian MALTs [7]. This chapter briefly summarizes one particular feature of this tissue structure, the distribution of $\mathrm{T}$ and $\mathrm{B}$ cells, antigen-sampling cells and dendritic cells (DCs) in each mucosal organ.

Unlike human skin, that of fish is coated with a mucosal layer due to a lack of keratinisation, with the skin mucus being the first physical, chemical and biological barrier against infection, desiccation and contact injury [7], [8]. Studies using antibodies against $\mathrm{T}$ and $\mathrm{B}$ cell markers have shown that $\mathrm{B}$ and/or $\mathrm{T}$ cells are abundant in the skin 
epidermis of rainbow trout and common carp [10],[11],[12]. CD8 ${ }^{+}$MHC class $\mathrm{II}^{+}$DCs have been identified in rainbow trout skin, and exhibited functional features similar to those of mammalian DC subsets [13].

Gills are respiratory organs for aquatic animals and serve as a portal of entry for microorganisms from the aqueous environment. Thus, gills are also coated with mucus to protect against invading pathogens. Organized interbranchial lymphoid tissue (ILT) has been found within the gill epithelium of Atlantic salmon [14], and was shown to be a site for $T$ cell aggregation and expression of T cell marker genes [9, 15]. Further investigation has shown that the ILT extends as a diffuse mucosal lymphoid tissue throughout the trailing edge of the gill filament [16]. Recently, Kato et al. [17] characterised two types of antigen-sampling cells within trout gill epithelium, including resident DC/macrophagelike cells, that exhibited phenotypic characteristics of M cells. M-type antigen-sampling cells expressing MHC class II were significantly increased in the gill epithelium following bath vaccination, suggesting that antigen-sampling cells are involved in direct antigen presentation to T cells in the gill mucosal tissue of teleost fish.

The intestinal mucosa is an important port of entry for many pathogens. Although fish intestine lacks organized lymphoid tissues, such as Peyer's patches, and while these secondary lymphoid tissues are present within mammals, there is evidence that fish intestine also acts as an immune organ for the generation of adaptive immunity. In support of this, intraepithelial lymphocytes (IELs) are abundant here [18], and many immunerelated genes are expressed [19]. Using several antibodies that recognize T cell markers, high numbers of these cells were detected in the intestinal epithelium of both carp and seabass [20],[21]. $\operatorname{IgM}^{+}$and $\operatorname{IgT}^{+}$cells were identified all along the intestinal tract, with the exception of the stomach, in rainbow trout [22]. Antigen-sampling cells sharing some 
morphological similarities with mammalian M cells and macrophage-like cells have been identified in salmon intestine [23],[24],[25]. In addition to the gills and skin, CD8 ${ }^{+}$DCs are present within rainbow trout intestinal lamina propria, where they exhibit significant phenotypical and functional differences from gill CD8 ${ }^{+}$DCs [26].

The olfactory organ is a vitally important chemosensory organ for teleost fish as well as other vertebrates, while it also provides an entrance for pathogenic microorganisms living in aquatic environments. A diffuse network of myeloid and lymphoid cells within olfactory organs has been recently discovered in rainbow trout [27] [28]. The predominant $\mathrm{B}$ cell subset found in the trout nasal cavity is $\operatorname{IgT}^{+} \mathrm{B}$ cells, as in other mucosal organs, whereas IgM ${ }^{+}$B cells also exist [27]. Furthermore, the genes involved in adaptive and innate immunity are expressed in nasal tissues. Sepahi et al. have demonstrated the presence of two different microenvironments in the trout olfactory organ: mucosal and neuroepithelial, [29]. $\mathrm{CD} 8 \alpha^{+}$cells, which display a phenotype of $\mathrm{CD}^{+} \mathrm{T}$ cells, are clustered at the mucosal tip of the olfactory lamellae, whereas relatively low numbers are present in the neuroepithelial region. MHC class $\mathrm{II}^{+}$cells are located closer to the lumen of the nasal cavity than the neuroepithelial region. The distribution of immune cells in the two compartments suggests that teleost olfactory organs create an environment for unique regional immunity without interfering with sensory functions.

These findings indicate that such mucosal organs are the first barriers against pathogen entry, and are important sites for antigen-sampling and presenting as well as generation of antigen-specific $\mathrm{T}$ and $\mathrm{B}$ cells in teleost fish. Therefore, the key to success for developing fish mucosal vaccines may involve efficient delivery of antigens into these mucosal tissues with subsequent generation of antigen-specific $\mathrm{T}$ and $\mathrm{B}$ cells. 


\section{Possible delivery routes for mucosal vaccines}

Intraperitoneal (i.p.) injection is the most commonly employed method of administration for commercial fish vaccines, as i.p. injections reliably induce effective systemic adaptive immunity [30][31]. Adaptive immune responses against bacteria, viruses and parasites while following several routes of mucosal immunisations have been investigated in many fish species (Table 1). This chapter describes candidate vaccine delivery routes that may conceivably activate adaptive immunity in mucosal organs, and discusses their potential with comparison to i.p. injection.

\subsection{Immersion vaccinations}

In 1976, Amend and Fender demonstrated uptake of bovine serum albumin (BSA) into juvenile trout blood following exposure to a BSA solution with hyperosmotic treatment, indicating that immersion immunisation is an effective method for antigen administration into small fish [32]. This was the first report to propose an immersion vaccination method for teleost fish. Immersion vaccination is now a popular method within aquaculture fisheries, and has been shown to be effective against various viruses and bacteria in many fish species [33], [34]. The primary site of antigen uptake for immersion vaccination is the skin, although gills are also portal entry sites for antigens [35], [36]. This method has several advantages in that a large number of fish can be treated simultaneously with a single vaccination. Furthermore, it can also be used for larvae or juvenile fish that are too small to be injected, although a developmental stage should be carefully selected in order to successfully vaccinate without inducing immune-tolerance. Thus, knowledge concerning when juvenile fish are immune-competent is essential in order to plan an appropriate time point for vaccination [37]. In addition, it is generally accepted that 
immersion vaccinations are less labor-intensive, and fewer safety issues exist for administrators in comparison with i.p. vaccine injections. However, immersion vaccine efficacy remains inferior to that of i.p. administered vaccines. To overcome this issue, several delivery techniques for immersion vaccinations have been developed to provide better protection, including: spray [38], [39], hyperosmotic dip [40], [41], [42], [43], low [48].

161 frequency sonophoresis [44],[45] and flush exposure [46]. Improvements of immersion vaccines in many fish species have been summarized in several recent reviews [34][47]

\subsection{Percutaneous administration via stamp injection}

'Stamp' vaccination utilising a multiple puncture instrument is one method for percutaneous administration, and has been used for BCG vaccination in humans. This multiple puncture method in combination with immersion vaccination has been applied in fish [49] (Fig. 1A). This combined method has several advantages over the two individual techniques; since higher efficacy was obtained when compared with immersion alone, this technique could be applicable for vaccines in which protection is effective following injection but not immersion. In addition, it enables vaccination of juvenile fish that are too small and are highly sensitive to handling stress to be injected. However, the types of immune systems and cells that are inducible by this means of vaccination remains poorly understood, while it can presumably induce a more efficient mucosal adaptive immunity within the skin as compared with either immersion or i.p. injection alone. Nakanishi et al. reported that vaccination of rainbow trout with formalinkilled Streptococcus iniae by this method provided protection as effective as that via i.p. injection, indicating the possibility that this technique could be applicable to aquaculture 
fishes [49].

Recently, we developed a method to investigate local immune responses in vivo after subcutaneous antigen administration by using transparent fish fins. Administration of zymosan into the dorsal fin membrane induced migration of granulocytes to the injection site in a dose-dependent manner, which could be observed macroscopically due to transparency of the fin membrane (Fig. 3). This technique allowed us to investigate phagocytic and respiratory burst activities of granulocytes in vivo without any in vitro cellular treatment [50]. We obtained similar results following injection of Staphylococcus aureus bacterial antigen (unpublished data). We also looked at the migration/accumulation of immune cells at the fin after PHA injection and found that the increase of granulocytes at 1 day post-injection followed by macrophages and lymphocytes, including CD4- $1^{+}$and CD $8 \alpha^{+}$T cells, showed the highest number at 5 days after injection. Interestingly, CD4-1 ${ }^{+}$lymphoblasts appeared 3 days post-PHA injection (unpublished data). These results suggested that both innate and adaptive immunity are induced following PHA injection into the fin. This technique provides a unique tool that could lead to a better understanding of the mechanisms of local immune responses after antigen administration within the skin or fin.

\subsection{Oral administration and intubation}

Successful oral vaccination against a fish pathogen was first reported in 1942 [51]. This study demonstrated protection of trout against challenge with the bacterium Aeromonas salmonicida after feeding for approximately 70 consecutive days upon inactivated bacteria. To date, oral vaccine delivery strategies for teleost fish have been continuously improved by many fish vaccinologists, and is currently one of the most popular 
vaccination deliveries for aquaculture fishes.

202 Oral vaccination, which administrates vaccines with food, is the ideal delivery method for administrators as it requires the least amount of labour when compared to any other delivery method. Oral vaccination is also optimal for fish in that it does not incur additional stress. However, there remain several issues that need to be overcome in order to obtain higher efficacy of oral vaccines. Administered antigens are degraded within the gastric fish microenvironment, and vaccine components are often digested before they are able to prime immune cells. Recent reviews have summarized the current knowledge on experimental oral vaccines while focusing on the encapsulation of antigens to protect them from gastric degradation [52], [53]. Encapsulation can be accomplished by use of various materials including polymers such as alginate microparticles [54], [55], chitosan [56], liposomes [57], MicroMatrix and poly(D,L-lactic-co-glycolic acid) (PLGA) [58] and have been applied to oral vaccination platforms against various pathogens in teleost fishes. Furthermore, oral vaccination employing bioencapsulation in live vehicles such as the brine shrimp Artemia [59], rotifers and water fleas [60] has been developed for larval carp [65]. The conditions for oral vaccination, such as vaccine type and encapsulation 
effect, should be considered for each pathogen and/or fish species. Another issue involves suppression of cellular and/or humoral immune responses as a result of oral tolerance [66]. Since it is presumed that repetitive antigen administration, timing of fish developmental stages, temperature, and type of antigens are all factors involved in the induction of tolerance in fish [67], [68], [69], administrators should be mindful when they orally vaccinate fish. expected when compared with oral administration.

Oral intubation is a method that allows for reliable antigen administration into the gut or stomach. Although this method is utilised as an experimental model for oral immunisation, it may be difficult to apply practically within the context of mucosal vaccines [70]. However, as it can directly deliver vaccines to the gut, higher efficacy is

\subsection{Anal intubation}

Anal intubation using soft thin tubes is another route of direct administration of vaccines into the intestine (Fig. 1B) and is considered to waste less vaccine when compared to oral administration. This method can allow for complete infusion of the vaccine into the fish body; thus, it would be expected to directly activate immune cells within the intestine and subsequently induce host adaptive immunity. Furthermore, this method avoids vaccine degradation in the highly acidic environment of the stomach. Since anal vaccination has been shown to be effective for inducing both cell-mediated and humoral responses in local and systemic adaptive immunity [71], [72], [73], it is expected to be a more effective vaccination platform than i.p. injection or oral administration. While this method requires highly skilled administrators and is more time-intensive, it is likely in incur fewer safety issues for administrators than injection. Therefore, for practical application of this method, 
development of novel equipment and easy to employ procedures is critical.

250

\subsection{Direct administration to gills (per-gill administration)}

252

253

Direct exposure of antigens to the gills has been performed in both common carp and ginbuna crucian carp [57], [74], [75]. This method has been established for artificially infecting carp with KHV and has resulted in reliable development of KHV disease [57],[75]. The antigen solution is first dropped onto the gills via pipette (Fig. 1C). After this treatment, fish are maintained in the air for 5 min to allow the antigen to adsorb onto gill tissue. To avoid drying of the body surface, the fish is wrapped with a wet towel during the absorption process. This method enables direct delivery of antigens into the gills and thus could be anticipated to induce efficient adaptive immunity. We applied this technique for evaluation of the adaptive immune response via gill-only sensitization with live virus using clonal ginbuna crucian carp. Consequently, both cell-mediated and humoral immune responses could be induced by this administration, suggesting that gillonly sensitization is sufficient to generate systemic adaptive immunity [74]. However, the protective effect of this method has not yet been investigated, and the cellular activities induced by gill antigen administration did not compare with those following i.p. injection. Thus, further studies are needed to elucidate the efficacy and feasibility of "per-gill vaccination”.

As described above, the gills are the only mucosal organ of fish containing organized lymphoid tissue, which includes various immune cells. Since the gill is a target organ for many infectious agents, this method could provide strong local immunity at this primary infection site. Thus, gill-only administration is a method of mucosal delivery that can effectively prime host adaptive immunity within these important organs. 


\subsection{Nasal immunisation}

275

276

277

Nasal vaccination is a method in which a vaccine solution is dropped into both fish nares, which can rapidly stimulate immune cells within the nasal cavity [27], [76](Fig. 1D). An experimental model using two vaccines within rainbow trout, the live attenuated infectious haematopoietic necrosis virus (IHNV) and enteric redmouth (ERM) vaccines, showed that nasal vaccination can elicit strong host immunity and provide protection against the infections. It has been shown that nasal administration is as effective as injection of vaccines in terms of protection. Interestingly, a series of studies demonstrated that dual vaccination against two different pathogens via the nasal route was a very effective vaccination strategy for use in aquaculture, particularly when each nare was used separately during delivery [77]. Salinas et al. demonstrated that nasal vaccination can elicit high levels of protection against IHNV and ERM within young trout at 360, 450, and 1050 days old [76]. However, it should be noted that nasal delivery of live attenuated IHNV vaccine caused significant mortalities in 360-day-old trout (with average weight of $2.37 \mathrm{~g}$ ). These results indicate that nasal vaccination is efficient in protecting juvenile fish, but that administrators should take care concerning the developmental stage of fish when utilizing live vaccines by this method.

Safety is a concern for nasal vaccines because the olfactory nerve connects the nasal cavity directly to the central nervous system (CNS). To evaluate the safety of the live attenuated IHNV nasal vaccine in rainbow trout, Larragoite et al. demonstrated that nasal delivery led to minimal presence of viral RNA in the brains of vaccinated trout, indicating a low probability that nasal vaccination causes adverse health effects in vaccinated fish. This finding supports that nasal vaccination can be acceptable for use in aquaculture 
fishes [78].

Although nasal vaccination needs to be examined in fish species other than rainbow trout, these findings clearly indicate that this vaccination platform could have the potential for development of a practical and effective means of providing mucosal vaccinations in fish.

\section{Adaptive immune responses following mucosal immunization}

The primary advantage of mucosal vaccination is to induce adaptive immunity within both local and systemic organs. Recent reviews have outlined that mucosal immunisation is capable of eliciting local and systemic immune responses to various pathogens in many fish species [34],[31],[48],[79]. In this chapter we highlight studies of local and systemic immune responses of IgT and IgM following immunisation. Furthermore, we discuss how mucosal immunisation with exogenous antigens can effectively induce cell-mediated immunity.

\subsection{IgM and IgT responses following mucosal immunisation}

IgM and IgT antibody responses can be used to evaluate humoral adaptive immunity following mucosal vaccination $[7,18]$. IgM plays an important role in systemic immunity, and IgT has a specialized role in gut mucosal immunity and functionally resembles mammalian IgA [80]. Accumulating evidence has shown that vaccinations via various mucosal routes can induce systemic and local immune responses of these immunoglobulin (Ig) classes [7], [81], [82].

Oral administration with encapsulated or yeast-displayed vaccines induced upregulation of IgT and IgM transcription in both local and systemic organs of several fish species [55], 
[56], [62],[83]. It has been reported that either mucosal, oral, or anal immunisation can induce equal levels of systemic IgM titers with intramuscular or i.p. injection in several fish species [71], [72], [84], whereas some studies showed that IgM antibody titers obtained from mucosally-vaccinated fish were not detectable or were lower than those of i.p. injected fish [85],[86]. Furthermore, anal vaccinations showed a greater increase of IgM antibodies not only in serum but also within gut and skin mucus [72], [85]. Immersion vaccination also induced upregulation of IgM and IgT genes in flounder [47], and turbot elicited a much stronger IgT response in local organs compared with vaccination by injection [87]. In rainbow trout, immersion or anal immunisations with an attenuated Flavobacterium psychrophilum induced significant upregulation of IgT in gills or intestines, respectively, whereas they did not induce a systemic IgM response [88]. These studies indicated that priming of the gut or skin efficiently induce IgT and IgM production in both mucosal and systemic organs and demonstrated higher efficacy than i.p. injection.

Direct administration of virus onto gills induced IgM production as determined from ginbuna crucian carp serum, indicating that priming onto the gills alone can induce systemic IgM responses [74]. However, as the antibody response was not comparable to that of systemic vaccination, it remains unclear whether gill vaccination is more effective than systemic vaccinations. Since it has been reported that IgT and IgM genes are expressed in ILT in adult Atlantic salmon, ILT may be important lymphoid tissue for B cell activations [16]. To demonstrate its utility within fish vaccination however, further study is needed to understand the humoral immunity induced following stimulation via ILT.

The olfactory epithelium of rainbow trout contains greater numbers of B cells than that 
of the gut and skin, and the predominant $\mathrm{B}$ cell subset in nasal cavity is $\operatorname{IgT}^{+}$and not $\operatorname{IgM}^{+}$

[27]. A recent study has shown that bath infection with the parasite Ichthyophthirius multifiliis elicited strong parasite-specific IgT responses within nasal mucosal tissue, with accumulation of $\operatorname{IgT}^{+} \mathrm{B}$ cells in the nasal epidermis following immersion infection [89]. These findings suggested that adaptive immune responses in the nasal cavity are similar to those in other mucosal tissues and that parasite-antigen-specific IgT is generated within nasal cavities. Furthermore, another recent study employing the ERM nasal vaccination in the rainbow trout model investigated profiles of the systemic and local B cell repertoire using 5'-RACE and a deep sequencing-based approach [90]. Consequently, nasal immunisation with the ERM vaccine revealed unique dynamics of IgM and IgT repertoires at both systemic (spleen) and local (nasal) sites, providing evidence based on Ig-diversity that IgT and IgM responses were triggered by nasal vaccination. These findings indicate that the principles for shaping a mucosal antibody repertoire in fish are similar to those in mammals.

\subsection{Cell-mediated immunity of $\mathrm{CD8}^{+}$cells following mucosal immunisations}

Cell-mediated immunity (CMI) plays an important role in protection against intracellular bacterial and viral infections. Typically, attenuated live and DNA vaccines lead to production of endogenous antigens within host cells, with the host cells then presenting these antigens on MHC class I. Thus, these replicable vaccines are capable of inducing antigen-specific cytotoxic T cells (CTLs) within host adaptive immunity. On the other hand, since exogenous antigens, including those of inactivated vaccines, cannot be presented on MHC class I in the conventional route [91], vaccination with exogenous antigens does not efficiently induce effective CMI. However, according to several reports 
there remains the possibility that fish CTLs can be efficiently elicited via mucosal immunisation with an exogenous antigen without any adjuvant. For instance, oral intubation with formalin-inactivated crucian carp haematopoietic necrosis virus (CHNV) provided efficient protection and induced significant cell-mediated cytotoxicity against CHNV-syngeneic cells within ginbuna carp [92]. In addition, we have recently demonstrated that anal intubation with formalin-inactivated CHNV induced the generation of virus-specific CD8 ${ }^{+} \mathrm{T}$ cells and provided efficient systemic CMI in ginbuna crucian carp [73]. This study also indicated that the posterior portion of the intestine is an important site for generating virus-specific CTLs via administration of inactivated vaccine. Furthermore, Sato et al. [93], [94] showed that antigen-specific cell-mediated cytotoxicity of leukocytes from both common and crucian carp can be induced as a result of anal or oral intubation with allogeneic or hapten-modified cells. Cytotoxic activity induced by anal immunisation was higher than that resulting from i.p. administration, suggesting that this route is effective for eliciting systemic CMI. Transcription analyses have demonstrated that oral or bath vaccination with inactivated viruses induces upregulation of MHC class I and CD8 mRNA in grouper fish [95], [96], indicating that vaccination with inactivated virus can also induce CMI. Together, these findings suggested that mucosal administration of exogenous antigens can elicit antigen-specific $\mathrm{CD}^{+}$CTLs in teleost fish.

Although detailed mechanisms concerning the generation of antigen-specific CTLs remain unknown, we propose the hypothesis that teleost dendritic cells in mucosal tissues more frequently and actively present exogenous antigens on MHC class I via crosspresentation as compared to mammalian dendritic cells (Fig. 2). Teleost DCs have already been found in the intestine, gills and skin where they exhibit varying phenotypic and 
functional characteristics, suggesting the existence of distinct DC subsets in the mucosal tissues [97], [98], [99]. Understanding mucosal DC functions may shed light upon the development of effective vaccines against both viral and intracellular bacterial infections. Olfactory sensory neurons are directly connected to the CNS, and have been shown to be involved in the immune systems of teleost fish [28]. A recent study has shown that nasal viral delivery induces ultra-rapid infiltration of CD8 $\alpha^{+} \mathrm{T}$ cells to the olfactory organ from the olfactory bulb with the response being mediated by neuronal signals via a tropomyosin-related kinase A receptor (TrkA)-dependent pathway [100]. Infiltrating $\mathrm{CD} 8 \alpha^{+} \mathrm{T}$ cells in the olfactory organ expressed perforin and granzyme A. These findings suggest that CTLs in the nervous system may play a role in killing virus-infected neurons in order to stop progression of infection to the olfactory bulb and other CNS regions. A Lewis rat model using neurotropic Borna disease virus demonstrated that neurons are MHC class I-dependent target cells of $\mathrm{CD}^{+} \mathrm{T}$ cells [101]. Additionally, a murine model of LCMV infection has shown that virus-infected parenchymal cells are eliminated by CTLs in an MHC class I-dependent manner, whereas infected cells are eliminated independently of MHC class I expression within the CNS linings, including the meninges and ependyma [102],[103]. These findings indicate that the effector functions of CTLs in the CNS exist there within distinct anatomical niches. Although some evidence shows that CTLs are one of the key players in prevention of viral infection in the CNS, to the best of our knowledge their contribution in control of viral infection in these regions is largely unknown in virtually all vertebrates. Previous study has shown that the classical MHC class I molecule, Onmy-UBA, is expressed in some neurons including within the CNS in early developmental stages of the rainbow trout, suggesting that neural cells are targeted by CTLs in teleost fish [104]. Therefore, further exploration of CTL functions 
417 following nasal immunisation using teleost fish could provide a compelling vertebrate 418 model for understanding neuron-CTL interactions.

419 Many aquatic viruses with neurotropic characteristics cause serious mortality for farmed 420 fish, resulting in severe economic losses in world aquaculture. Furthermore, the 421 understanding of teleost CTL function in the CNS may very well contribute to the 422 development of effective mucosal vaccines against neurotropic viruses within teleost fish.

\section{Future studies on fish mucosal immunity}

425 Recent immunological research in mammals has demonstrated that tissue-specific resident memory $\mathrm{T}$ cells $\left(\mathrm{T}_{\mathrm{RM}}\right)$ in peripheral non-lymphoid tissues, such as the mucosal tissues of the respiratory and digestive tract, are key players for eliciting long-term memory via vaccination [105], [106], [107],. Although the induction of $\mathrm{T}_{\mathrm{RM}}$ is influenced by a number of factors, including the type of vaccine and adjuvant administered, mucosal vaccination is more effective than systemic delivery[108]. $\mathrm{T}_{\mathrm{RM}}$ have not yet been characterized in teleost fishes, although many studies have shown that $\mathrm{T}$ cells are abundant in various tissues [109], [110], [111]. Direct mucosal administration may be utilised to investigate roles of circulatory and resident $\mathrm{T}$ cells in both mucosal lymphoid cells and non-lymphoid tissues. Furthermore, the intra-fin administration method could be used to analyze local immune responses of $\mathrm{T}$ cells against various antigens. We are currently analyzing local immune responses to protozoan parasites using this technique (unpublished data). Understanding the recruitment or residence of $\mathrm{T}$ cells, B cells and DCs may provide clues for developing novel mucosal vaccine delivery platforms and practical mucosal vaccines for teleost fish. 
441

442

443

444

445

446

447

448

449

450

451

452

453

454

455

456

457

458

459

460

461

462

463

464

\section{Acknowledgements}

This work was supported in part by the Japan Society for the Promotion of Science KAKENHI (grant numbers: JP26450286, JP17K07939 and JP16H04984). The authors would like to thank Haruko Sakanaka and Seisuke Tajimi for assistance in creating Figures 1 and 2, respectively. The authors would like to thank Enago (www.enago.jp) for the English language review.

\section{References}

[1] N. Lycke, Recent progress in mucosal vaccine development: potential and limitations, Nat. Rev. Immunol. 12 (2012) 592-605. doi:10.1038/nri3251.

[2] F. Takaiwa, Y. Wakasa, H. Takagi, T. Hiroi, Rice seed for delivery of vaccines to gut mucosal immune tissues, Plant Biotechnol. J. 13 (2015) 1041-1055. doi:10.1111/pbi.12423.

[3] S. Rosales-Mendoza, C. Angulo, B. Meza, Food-grade organisms as vaccine biofactories and oral delivery vehicles., Trends Biotechnol. 34 (2016) 124-136. doi:10.1016/j.tibtech.2015.11.007.

[4] S. Şenel, M.J. Rathbone, M. Cansız, I. Pather, Recent developments in buccal and sublingual delivery systems, Expert Opin. Drug Deliv. 9 (2012) 615-628. doi:10.1517/17425247.2012.676040.

[5] H. Kraan, H. Vrieling, C. Czerkinsky, W. Jiskoot, G. Kersten, J.-P. Amorij, Buccal and sublingual vaccine delivery, J. Control. Release. 190 (2014) 580-592. doi:10.1016/j.jconrel.2014.05.060.

[6] D. Calderon-Nieva, K.B. Goonewardene, S. Gomis, M. Foldvari, Veterinary vaccine nanotechnology: pulmonary and nasal delivery in livestock animals., 
Drug Deliv. Transl. Res. 7 (2017) 558-570. doi:10.1007/s13346-017-0400-9.

[7] I. Salinas, The mucosal immune system of teleost fish., Biology (Basel). 4 (2015) 525-39. doi:10.3390/biology4030525.

[8] I. Salinas, S. Magadán, Omics in fish mucosal immunity., Dev. Comp. Immunol. 75 (2017) 99-108. doi:10.1016/j.dci.2017.02.010.

[9] E.O. Koppang, U. Fischer, L. Moore, M.A. Tranulis, J.M. Dijkstra, B. Kollner, L. Aune, E. Jirillo, I. Hordvik, Salmonid T cells assemble in the thymus, spleen and in novel interbranchial lymphoid tissue, J. Anat. 217 (2010) 728-739. doi:10.1111/j.1469-7580.2010.01305.x [doi].

[10] J.H.W.M. Rombout, P.H.M. Joosten, M.Y. Engelsma, A.P. Vos, N. Taverne, J.J. Taverne-Thiele, Indications for a distinct putative $\mathrm{T}$ cell population in mucosal tissue of carp (Cyprinus carpio L.), Dev. Comp. Immunol. 22 (1998) 63-77. doi:10.1016/S0145-305X(97)00048-7.

[11] F. Takizawa, J.M. Dijkstra, P. Kotterba, T. Korytar, H. Kock, B. Kollner, B. Jaureguiberry, T. Nakanishi, U. Fischer, The expression of CD8alpha discriminates distinct $\mathrm{T}$ cell subsets in teleost fish, Dev. Comp. Immunol. 35 (2011) 752-763. doi:10.1016/j.dci.2011.02.008; 10.1016/j.dci.2011.02.008.

[12] Z. Xu, D. Parra, D. Gómez, I. Salinas, Y.-A. Zhang, L. von Gersdorff Jørgensen, R.D. Heinecke, K. Buchmann, S. LaPatra, J.O. Sunyer, Teleost skin, an ancient mucosal surface that elicits gut-like immune responses., Proc. Natl. Acad. Sci. U. S. A. 110 (2013) 13097-102. doi:10.1073/pnas.1304319110.

[13] A.G. Granja, E. Leal, J. Pignatelli, R. Castro, B. Abós, G. Kato, U. Fischer, C. Tafalla, Identification of teleost skin CD8 $\alpha^{+}$dendritic-like cells, representing a potential common ancestor for mammalian cross-presenting dendritic cells., J. 
[14] E. Haugarvoll, I. Bjerkas, B.F. Nowak, I. Hordvik, E.O. Koppang, Identification and characterization of a novel intraepithelial lymphoid tissue in the gills of Atlantic salmon, J. Anat. 213 (2008) 202-209.

[15] I.B. Aas, L. Austbø, M. König, M. Syed, K. Falk, I. Hordvik, E.O. Koppang, Transcriptional characterization of the T cell population within the salmonid interbranchial lymphoid tissue, J. Immunol. 193 (2014) 3463-3469. doi:10.4049/jimmunol.1400797.

[16] A.S. Dalum, L. Austbø, H. Bjørgen, K. Skjødt, I. Hordvik, T. Hansen, P.G. Fjelldal, C.M. Press, D.J. Griffiths, E.O. Koppang, The interbranchial lymphoid tissue of Atlantic salmon (Salmo salar L) extends as a diffuse mucosal lymphoid tissue throughout the trailing edge of the gill filament., J. Morphol. 276 (2015) 1075-88. doi:10.1002/jmor.20403.

[17] G. Kato, H. Miyazawa, Y. Nakayama, Y. Ikari, H. Kondo, T. Yamaguchi, M. Sano, U. Fischer, A novel antigen-sampling cell in the teleost gill epithelium with the potential for direct antigen presentation in mucosal tissue, Front. Immunol. 9 (2018) 2116. doi:10.3389/fimmu.2018.02116.

[18] J.H.W.M. Rombout, G. Yang, V. Kiron, Adaptive immune responses at mucosal surfaces of teleost fish., Fish Shellfish Immunol. 40 (2014) 634-43. doi:10.1016/j.fsi.2014.08.020.

[19] S.A.M. Martin, C.E. Dehler, E. Król, Transcriptomic responses in the fish intestine, Dev. Comp. Immunol. 64 (2016) 103-117. doi:10.1016/j.dci.2016.03.014.

[20] S. Picchietti, F.R. Terribili, L. Mastrolia, G. Scapigliati, L. Abelli, Expression of 
lymphocyte antigenic determinants in developing gut-associated lymphoid tissue

of the sea bass Dicentrarchus labrax (L.)., Anat. Embryol. (Berl). 196 (1997) 457-63. http://www.ncbi.nlm.nih.gov/pubmed/9453366 (accessed August 2, 2019).

[21] J.H. Rombout, L. Abelli, S. Picchietti, G. Scapigliati, V. Kiron, Teleost intestinal immunology, Fish Shellfish Immunol. 31 (2011) 616-626. doi:10.1016/j.fsi.2010.09.001 [doi].

[22] N.A. Ballesteros, R. Castro, B. Abos, S.S. Rodríguez Saint-Jean, S.I. PérezPrieto, C. Tafalla, The pyloric caeca area is a major site for $\operatorname{IgM}^{+}$and $\operatorname{IgT}^{+} \mathrm{B}$ cell recruitment in response to oral vaccination in rainbow trout, PLoS One. 8 (2013) e66118. doi:10.1371/journal.pone.0066118.

[23] B. Fuglem, E. Jirillo, I. Bjerkås, H. Kiyono, T. Nochi, Y. Yuki, M. Raida, U. Fischer, E.O. Koppang, Antigen-sampling cells in the salmonid intestinal epithelium., Dev. Comp. Immunol. 34 (2010) 768-74. doi:10.1016/j.dci.2010.02.007.

[24] G. Løkka, E.O. Koppang, Antigen sampling in the fish intestine., Dev. Comp. Immunol. 64 (2016) 138-49. doi:10.1016/j.dci.2016.02.014.

[25] G. Løkka, K. Falk, L. Austbø, E.O. Koppang, Uptake of yeast cells in the Atlantic salmon (Salmo salar L.) intestine., Dev. Comp. Immunol. 47 (2014) 7780. doi:10.1016/j.dci.2014.07.005.

[26] I. Soleto, A.G. Granja, R. Simón, E. Morel, P. Díaz-Rosales, C. Tafalla, Identification of $\mathrm{CD} 8 \alpha^{+}$dendritic cells in rainbow trout (Oncorhynchus mykiss) intestine, Fish Shellfish Immunol. 89 (2019) 309-318. doi:10.1016/j.fsi.2019.04.001. 
[27] L. Tacchi, R. Musharrafieh, E.T. Larragoite, K. Crossey, E.B. Erhardt, S.A.M. Martin, S.E. LaPatra, I. Salinas, Nasal immunity is an ancient arm of the mucosal immune system of vertebrates, Nat. Commun. 5 (2014) 5205. doi:10.1038/ncomms6205.

[28] A. Sepahi, I. Salinas, The evolution of nasal immune systems in vertebrates., Mol. Immunol. 69 (2016) 131-8. doi:10.1016/j.molimm.2015.09.008.

[29] A. Sepahi, E. Casadei, L. Tacchi, P. Muñoz, S.E. LaPatra, I. Salinas, Tissue microenvironments in the nasal epithelium of rainbow trout (Oncorhynchus mykiss ) define two distinct $\mathrm{CD} 8 \alpha^{+}$cell populations and establish regional immunity, J. Immunol. 197 (2016) 4453-4463. doi:10.4049/jimmunol.1600678.

[30] S. Vinitnantharat, K. Gravningen, E. Greger, Fish vaccines., Adv. Vet. Med. 41 (1999) 539-50. http://www.ncbi.nlm.nih.gov/pubmed/9890041 (accessed September 10, 2019).

[31] K.P. Plant, S.E. Lapatra, Advances in fish vaccine delivery, Dev. Comp. Immunol. 35 (2011) 1256-1262. doi:10.1016/j.dci.2011.03.007; 10.1016/j.dci.2011.03.007.

[32] D.F. Amend, D.C. Fender, Uptake of bovine serum albumin by rainbow trout from hypersmotic solutions: a model for vaccinating fish., Science. 192 (1976) 793-4. doi:10.1126/science.1265480.

[33] T. Nakanishi, M. Ototake, Antigen uptake and immune responses after immersion vaccination., Dev. Biol. Stand. 90 (1997) 59-68. http://www.ncbi.nlm.nih.gov/pubmed/9270835 (accessed June 12, 2019).

[34] H.M. Munang'andu, S. Mutoloki, Ø. Evensen, An overview of challenges limiting the design of protective mucosal vaccines for finfish., Front. Immunol. 6 
(2015) 542. doi:10.3389/fimmu.2015.00542.

562

563

564

565

566

567

568

569

570

571

572

573

574

575

576

577

578

579

580

581

582

583

584

[35] J.D. Moore, M. Ototake, T. Nakanishi, Particulate antigen uptake during immersion immunisation of fish: The effectiveness of prolonged exposure and the roles of skin and gill, Fish Shellfish Immunol. 8 (1998) 393-408. doi:10.1006/FSIM.1998.0143.

[36] M. Ototake, J.D. Moore, T. Nakanishi, Prolonged immersion improves the effectiveness of dilute vibrio Vaccine for rainbow trout., Fish Pathol. 34 (1999) 151-154. doi:10.3147/jsfp.34.151.

[37] A. Zapata, B. Diez, T. Cejalvo, C. Gutiérrez-de Frías, A. Cortés, Ontogeny of the immune system of fish., Fish Shellfish Immunol. 20 (2006) 126-36. doi:10.1016/j.fsi.2004.09.005.

[38] R.W. Gould, P.J. O’Leary, R.L. Garrison, J.S. Rohovec, J.L. Fryer, Spray vaccination : A method for the immunization of fish, Fish Pathol. 13 (1978) 6368. doi:10.3147/jsfp.13.63.

[39] O. Noraini, M.Y. Sabri, A. Siti-Zahrah, Efficacy of spray administration of formalin-killed Streptococcus agalactiae in hybrid Red Tilapia., J. Aquat. Anim. Health. 25 (2013) 142-8. doi:10.1080/08997659.2013.781553.

[40] R. Antipa, R. Gould, D.F. Amend, Vibrio anguillarum vaccination of sockeye salmon Oncorhynchus nerka (Walbaum) by direct and hyperosmotic immersion, J. Fish Dis. 3 (1980) 161-165. doi:10.1111/j.1365-2761.1980.tb00199.x.

[41] M.O. Huising, T. Guichelaar, C. Hoek, B.M.L. Verburg-van Kemenade, G. Flik, H.F.J. Savelkoul, J.H.W.M. Rombout, Increased efficacy of immersion vaccination in fish with hyperosmotic pretreatment., Vaccine. 21 (2003) 417893. http://www.ncbi.nlm.nih.gov/pubmed/14505897 (accessed May 4, 2019). 
[42] Y.-L. Gao, X.-Q. Tang, X.-Z. Sheng, J. Xing, W.-B. Zhan, Immune responses of flounder Paralichthys olivaceus vaccinated by immersion of formalin-inactivated Edwardsiella tarda following hyperosmotic treatment., Dis. Aquat. Organ. 116 (2015) 111-20. doi:10.3354/dao02909.

[43] Y. Gao, X. Tang, X. Sheng, J. Xing, W. Zhan, Antigen uptake and expression of antigen presentation-related immune genes in flounder (Paralichthys olivaceus) after vaccination with an inactivated Edwardsiella tarda immersion vaccine, following hyperosmotic treatment., Fish Shellfish Immunol. 55 (2016) 274-80. doi:10.1016/j.fsi.2016.05.042.

[44] C. Cobo, K. Makosch, R. Jung, K. Kohlmann, K. Knopf, Enhanced Aeromonas salmonicida bacterin uptake and side effects caused by low frequency sonophoresis in rainbow trout (Oncorhynchus mykiss)., Fish Shellfish Immunol. 36 (2014) 444-52. doi:10.1016/j.fsi.2013.12.010.

[45] C. Cobo Labarca, M. Makhutu, A.E. Lumsdon, K.D. Thompson, R. Jung, W. Kloas, K. Knopf, The adjuvant effect of low frequency ultrasound when applied with an inactivated Aeromonas salmonicida vaccine to rainbow trout (Oncorhynchus mykiss), Vaccine. 33 (2015) 1369-1374. doi:10.1016/j.vaccine.2015.01.027.

[46] D.P. Anderson, B. Merchant, O.W. Dixon, C.F. Schott, E.F. Lizzio, Flush exposure and injection immunization of rainbow trout to selected DNP conjugates, Dev. Comp. Immunol. 7 (1983) 261-268. doi:10.1016/0145305X(83)90007-1.

[47] Y. Du, X. Tang, X. Sheng, J. Xing, W. Zhan, The influence of concentration of inactivated Edwardsiella tarda bacterin and immersion time on antigen uptake 
and expression of immune-related genes in Japanese flounder (Paralichthys olivaceus), Microb. Pathog. 103 (2017) 19-28. doi:10.1016/j.micpath.2016.12.011.

[48] F. Buonocore, N. Nuñez-Ortiz, S. Picchietti, E. Randelli, V. Stocchi, L. Guerra, A. Toffan, F. Pascoli, A.M. Fausto, M. Mazzini, G. Scapigliati, Vaccination and immune responses of European sea bass (Dicentrarchus labrax L.) against betanodavirus, Fish Shellfish Immunol. 85 (2019) 78-84. doi:10.1016/J.FSI.2017.11.039.

[49] T. Nakanishi, I. Kiryu, M. Ototake, Development of a new vaccine delivery method for fish: percutaneous administration by immersion with application of a multiple puncture instrument., Vaccine. 20 (2002) 3764-9. http://www.ncbi.nlm.nih.gov/pubmed/12399207 (accessed June 12, 2019).

[50] Y. Matsuura, N. Takaoka, R. Miyazawa, T. Nakanishi, A simple and noninvasive method for analyzing local immune responses in vivo using fish fin, Dev. Comp. Immunol. 74 (2017) 136-143. doi:10.1016/j.dci.2017.04.016.

[51] D. C. B. Duff. The Oral Immunization of Trout Against Bacterium Salmonicida, J. Immunol. 44 (1942) 87-94.

[52] S. Mutoloki, H.M. Munang'andu, Ø. Evensen, Oral vaccination of fish - Antigen preparations, uptake, and immune induction, Front. Immunol. 6 (2015) 519. doi:10.3389/fimmu.2015.00519.

[53] C.W.E. Embregts, M. Forlenza, Oral vaccination of fish: Lessons from humans and veterinary species, Dev. Comp. Immunol. 64 (2016) 118-137. doi:10.1016/j.dci.2016.03.024.

[54] L. Chen, G. Klaric, S. Wadsworth, S. Jayasinghe, T.-Y. Kuo, Ø. Evensen, S. 
Mutoloki, Augmentation of the antibody response of Atlantic salmon by oral administration of alginate-encapsulated IPNV antigens, PLoS One. 9 (2014) e109337. doi:10.1371/journal.pone.0109337.

[55] N.A. Ballesteros, M. Alonso, S.R. Saint-Jean, S.I. Perez-Prieto, An oral DNA vaccine against infectious haematopoietic necrosis virus (IHNV) encapsulated in alginate microspheres induces dose-dependent immune responses and significant protection in rainbow trout (Oncorrhynchus mykiss)., Fish Shellfish Immunol. 45 (2015) 877-88. doi:10.1016/j.fsi.2015.05.045.

[56] S. Kole, S.S. Nazir Qadiri, S.-M. Shin, W.-S. Kim, J. Lee, S.-J. Jung, Nanoencapsulation of inactivated-viral vaccine using chitosan nanoparticles: Evaluation of its protective efficacy and immune modulatory effects in olive flounder (Paralichthys olivaceus) against viral haemorrhagic septicaemia virus (VHSV) infection., Fish Shellfish Immunol. 91 (2019) 136-147. doi:10.1016/j.fsi.2019.05.017.

[57] S. Yasumoto, Y. Kuzuya, M. Yasuda, T. Yoshimura, T. Miyazaki, Oral Immunization of common carp with a liposome vaccine fusing koi herpesvirus antigen, Fish Pathol. 41 (2006) 141-145. doi:10.3147/jsfp.41.141.

[58] S. Kole, S.S.N. Qadiri, S.-M. Shin, W.-S. Kim, J. Lee, S.-J. Jung, PLGA encapsulated inactivated-viral vaccine: Formulation and evaluation of its protective efficacy against viral haemorrhagic septicaemia virus (VHSV) infection in olive flounder (Paralichthys olivaceus) vaccinated by mucosal delivery routes., Vaccine. 37 (2019) 973-983. doi:10.1016/j.vaccine.2018.12.063.

[59] C.-C. Lin, J.H.-Y. Lin, M.-S. Chen, H.-L. Yang, An oral nervous necrosis virus 
vaccine that induces protective immunity in larvae of grouper (Epinephelus coioides), Aquaculture. 268 (2007) 265-273. doi:10.1016/J.AQUACULTURE.2007.04.066.

[60] K. Kawai, S. Yamamoto, R. Kusuda, Plankton-mediated oral delivery of Vibrio anguillarum vaccine to juvenile ayu., Nippon Suisan Gakkaishi. 55 (1989) 35-40. doi:10.2331/suisan.55.35.

[61] J.-Z. Zhao, L.-M. Xu, M. Liu, Y.-S. Cao, S.E. LaPatra, J.-S. Yin, H.-B. Liu, T.Y. Lu, Preliminary study of an oral vaccine against infectious hematopoietic necrosis virus using improved yeast surface display technology., Mol. Immunol. 85 (2017) 196-204. doi:10.1016/j.molimm.2017.03.001.

[62] S. Ahmadivand, M. Soltani, M. Behdani, Ø. Evensen, E. Alirahimi, R. Hassanzadeh, E. Soltani, Oral DNA vaccines based on CS-TPP nanoparticles and alginate microparticles confer high protection against infectious pancreatic necrosis virus (IPNV) infection in trout., Dev. Comp. Immunol. 74 (2017) 178189. doi:10.1016/j.dci.2017.05.004.

[63] K. Duan, X. Hua, Y. Wang, Y. Wang, Y. Chen, W. Shi, L. Tang, Y. Li, M. Liu, Oral immunization with a recombinant Lactobacillus expressing CK6 fused with VP2 protein against IPNV in rainbow trout (Oncorhynchus mykiss), Fish Shellfish Immunol. 83 (2018) 223-231. doi:10.1016/J.FSI.2018.09.034.

[64] C.W.E. Embregts, D. Rigaudeau, L. Tacchi, G.P. Pijlman, L. Kampers, T. Veselý, D. Pokorová, P. Boudinot, G.F. Wiegertjes, M. Forlenza, Vaccination of carp against SVCV with an oral DNA vaccine or an insect cells-based subunit vaccine, Fish Shellfish Immunol. 85 (2019) 66-77. doi:10.1016/j.fsi.2018.03.028. 
[65] C.W.E. Embregts, R. Tadmor-Levi, T. Veselý, D. Pokorová, L. David, G.F. Wiegertjes, M. Forlenza, Intra-muscular and oral vaccination using a Koi Herpesvirus ORF25 DNA vaccine does not confer protection in common carp (Cyprinus carpio L.)., Fish Shellfish Immunol. 85 (2019) 90-98. doi:10.1016/j.fsi.2018.03.037.

[66] H.L. Weiner, A.P. da Cunha, F. Quintana, H. Wu, Oral tolerance., Immunol. Rev. 241 (2011) 241-59. doi:10.1111/j.1600-065X.2011.01017.x.

[67] P.H.M. Joosten, M. Avilés-Trigueros, P. Sorgeloos, J.H.W.M. Rombout, Oral vaccination of juvenile carp (Cyprinus carpio) and gilthead seabream (Sparus aurata) with bioencapsulatedVibrio anguillarum bacterin, Fish Shellfish Immunol. 5 (1995) 289-299. doi:10.1006/FSIM.1995.0028.

[68] P.H. Joosten, M.Y. Engelsma, M.D. van der Zee, J.H. Rombout, Induction of oral tolerance in carp (Cyprinus carpio L.) after feeding protein antigens., Vet. Immunol. Immunopathol. 60 (1997) 187-96. http://www.ncbi.nlm.nih.gov/pubmed/9533276 (accessed June 9, 2019).

[69] S. Maurice, A. Nussinovich, N. Jaffe, O. Shoseyov, A. Gertler, Oral immunization of with modified recombinant A-layer proteins entrapped in alginate beads, Vaccine. 23 (2004) 450-459. doi:10.1016/j.vaccine.2004.06.022.

[70] J. Ji, R. Thwaite, N. Roher, Oral Intubation of Adult Zebrafish: A model for evaluating intestinal uptake of bioactive compounds, J. Vis. Exp. (2018). doi:10.3791/58366.

[71] J.W. Rombout, L.J. Blok, C.H. Lamers, E. Egberts, Immunization of carp (Cyprinus carpio) with a Vibrio anguillarum bacterin: indications for a common mucosal immune system., Dev. Comp. Immunol. 10 (1986) 341-51. 
http://www.ncbi.nlm.nih.gov/pubmed/3770268 (accessed April 30, 2019).

[72] M.D. Esteve-Gassent, B. Fouz, C. Amaro, Efficacy of a bivalent vaccine against eel diseases caused by Vibrio vulnificus after its administration by four different routes., Fish Shellfish Immunol. 16 (2004) 93-105. doi:10.1016/S10504648(03)00036-6.

[73] S. Tajimi, M. Kondo, T. Nakanishi, T. Nagasawa, M. Nakao, T. Somamoto, Generation of virus-specific CD8+ T cells by vaccination with inactivated virus in the intestine of ginbuna crucian carp, Dev. Comp. Immunol. 93 (2019) 37-44. doi:10.1016/j.dci.2018.12.009.

[74] T. Somamoto, Y. Miura, T. Nakanishi, M. Nakao, Local and systemic adaptive immune responses toward viral infection via gills in ginbuna crucian carp, Dev. Comp. Immunol. 52 (2015). doi:10.1016/j.dci.2015.04.016.

[75] T. Miyazaki, Y. Kuzuya, S. Yasumoto, M. Yasuda, T. Kobayashi, Histopathological and ultrastructural features of Koi herpesvirus (KHV)-infected carp Cyprinus carpio, and the morphology and morphogenesis of KHV., Dis. Aquat. Organ. 80 (2008) 1-11. doi:10.3354/dao01929.

[76] I. Salinas, S.E. LaPatra, E.B. Erhardt, Nasal vaccination of young rainbow trout (Oncorhynchus mykiss) against infectious hematopoietic necrosis and enteric red mouth disease., Dev. Comp. Immunol. 53 (2015) 105-11. doi:10.1016/j.dci.2015.05.015.

[77] S. LaPatra, S. Kao, E.B. Erhardt, I. Salinas, Evaluation of dual nasal delivery of infectious hematopoietic necrosis virus and enteric red mouth vaccines in rainbow trout (Oncorhynchus mykiss), Vaccine. 33 (2015) 771-776. doi:10.1016/j.vaccine.2014.12.055. 
[78] E.T. Larragoite, L. Tacchi, S.E. LaPatra, I. Salinas, An attenuated virus vaccine appears safe to the central nervous system of rainbow trout (Oncorhynchus mykiss) after intranasal delivery, Fish Shellfish Immunol. 49 (2016) 351-354. doi:10.1016/j.fsi.2016.01.006.

[79] Q. Wang, Y. Yu, X. Zhang, Z. Xu, Immune responses of fish to Ichthyophthirius multifiliis (Ich): A model for understanding immunity against protozoan parasites, Dev. Comp. Immunol. 93 (2019) 93-102. doi:10.1016/j.dci.2019.01.002.

[80] Y.-A. Zhang, I. Salinas, J. Li, D. Parra, S. Bjork, Z. Xu, S.E. LaPatra, J. Bartholomew, J.O. Sunyer, IgT, a primitive immunoglobulin class specialized in mucosal immunity., Nat. Immunol. 11 (2010) 827-35. doi:10.1038/ni.1913.

[81] D. Parra, F.E. Reyes-Lopez, L. Tort, Mucosal immunity and B cells in teleosts: Effect of vaccination and stress., Front. Immunol. 6 (2015) 354. doi:10.3389/fimmu.2015.00354.

[82] Z. Xu, F. Takizawa, D. Parra, D. Gómez, L. von Gersdorff Jørgensen, S.E. LaPatra, J.O. Sunyer, Mucosal immunoglobulins at respiratory surfaces mark an ancient association that predates the emergence of tetrapods, Nat. Commun. 7 (2016) 10728. doi:10.1038/ncomms10728.

[83] J.-Z. Zhao, L.-M. Xu, M. Liu, Y.-S. Cao, S.E. LaPatra, J.-S. Yin, H.-B. Liu, T.Y. Lu, Preliminary study of an oral vaccine against infectious hematopoietic necrosis virus using improved yeast surface display technology., Mol. Immunol. 85 (2017) 196-204. doi:10.1016/j.molimm.2017.03.001.

[84] S. Kole, S.S.N. Qadiri, S.-M. Shin, W.-S. Kim, J. Lee, S.-J. Jung, PLGA encapsulated inactivated-viral vaccine: Formulation and evaluation of its 
protective efficacy against viral haemorrhagic septicaemia virus (VHSV) infection in olive flounder (Paralichthys olivaceus) vaccinated by mucosal delivery routes., Vaccine. 37 (2019) 973-983. doi:10.1016/j.vaccine.2018.12.063.

[85] S. Vervarcke, F. Ollevier, R. Kinget, A. Michoel, Mucosal response in African catfish after administration of Vibrio anguillarum O2 antigens via different routes, Fish Shellfish Immunol. 18 (2005) 125-133. doi:10.1016/j.fsi.2004.06.004.

[86] P.B.B. Crosbie, B.F. Nowak, Immune responses of barramundi, Lates calcarifer (Bloch), after administration of an experimental Vibrio harveyi bacterin by intraperitoneal injection, anal intubation and immersion, J. Fish Dis. 27 (2004) 623-632. doi:10.1111/j.1365-2761.2004.00575.x.

[87] X. Tang, Y. Du, X. Sheng, J. Xing, W. Zhan, Molecular cloning and expression analyses of immunoglobulin tau heavy chain (IgT) in turbot, Scophthalmus maximus, Vet. Immunol. Immunopathol. 203 (2018) 1-12. doi:10.1016/j.vetimm.2018.07.011.

[88] M. Makesh, P.S. Sudheesh, K.D. Cain, Systemic and mucosal immune response of rainbow trout to immunization with an attenuated Flavobacterium psychrophilum vaccine strain by different routes., Fish Shellfish Immunol. 44 (2015) 156-63. doi:10.1016/j.fsi.2015.02.003.

[89] Y.-Y. Yu, W. Kong, Y.-X. Yin, F. Dong, Z.-Y. Huang, G.-M. Yin, S. Dong, I. Salinas, Y.-A. Zhang, Z. Xu, Mucosal immunoglobulins protect the olfactory organ of teleost fish against parasitic infection., PLoS Pathog. 14 (2018) e1007251. doi:10.1371/journal.ppat.1007251. 
[90] S. Magadan, L. Jouneau, P. Boudinot, I. Salinas, Nasal vaccination drives modifications of nasal and systemic antibody repertoires in rainbow trout, J. Immunol. 203 (2019) 1480-1492. doi:10.4049/jimmunol.1900157.

[91] L.A. Morrison, A.E. Lukacher, V.L. Braciale, D.P. Fan, T.J. Braciale, Differences in antigen presentation to MHC class I-and class II-restricted influenza virus-specific cytolytic T lymphocyte clones., J. Exp. Med. 163 (1986) 903-21. doi:10.1084/jem.163.4.903.

[92] A. Sato, N. Okamoto, Induction of virus-specific cell-mediated cytotoxic responses of isogeneic ginbuna crucian carp, after oral immunization with inactivated virus, Fish Shellfish Immunol. 29 (2010) 414-421. doi:10.1016/j.fsi.2010.04.017.

[93] A. Sato, T. Somamoto, H. Yokooka, N. Okamoto, Systemic priming of alloreactive cytotoxic cells in carp, following anal administration of allogeneic cell antigens., Fish Shellfish Immunol. 19 (2005) 43-52. doi:10.1016/j.fsi.2004.11.010.

[94] A. Sato, N. Okamoto, Characterization of the cell-mediated cytotoxic responses of isogeneic ginbuna crucian carp induced by oral immunisation with haptenmodified cellular antigens., Fish Shellfish Immunol. 24 (2008) 684-92. doi:10.1016/j.fsi.2007.11.009.

[95] Z. Ou-yang, P. Wang, X. Huang, J. Cai, Y. Huang, S. Wei, H. Ji, J. Wei, Y. Zhou, Q. Qin, Immunogenicity and protective effects of inactivated Singapore grouper iridovirus (SGIV) vaccines in orange-spotted grouper, Epinephelus coioides, Dev. Comp. Immunol. 38 (2012) 254-261. doi:10.1016/j.dci.2012.07.004; 10.1016/j.dci.2012.07.004. 
[96] Y.-H. Kai, Y.-C. Wu, S.-C. Chi, Immune gene expressions in grouper larvae (Epinephelus coioides) induced by bath and oral vaccinations with inactivated betanodavirus., Fish Shellfish Immunol. 40 (2014) 563-9. doi:10.1016/j.fsi.2014.08.005.

[97] A.G. Granja, E. Leal, J. Pignatelli, R. Castro, B. Abós, G. Kato, U. Fischer, C. Tafalla, Identification of Teleost Skin CD $8 \alpha^{+}$Dendritic-like cells, representing a potential common ancestor for mammalian cross-presenting dendritic cells., J. Immunol. 195 (2015) 1825-37. doi:10.4049/jimmunol.1500322.

[98] I. Soleto, U. Fischer, C. Tafalla, A.G. Granja, Identification of a potential common ancestor for mammalian cross-presenting dendritic cells in teleost respiratory surfaces., Front. Immunol. 9 (2018) 59. doi:10.3389/fimmu.2018.00059.

[99] I. Soleto, A.G. Granja, R. Simón, E. Morel, P. Díaz-Rosales, C. Tafalla, Identification of $\mathrm{CD} 8 \alpha^{+}$dendritic cells in rainbow trout (Oncorhynchus mykiss) intestine., Fish Shellfish Immunol. 89 (2019) 309-318. doi:10.1016/j.fsi.2019.04.001.

[100] A. Sepahi, A. Kraus, E. Casadei, C.A. Johnston, J. Galindo-Villegas, C. Kelly, D. García-Moreno, P. Muñoz, V. Mulero, M. Huertas, I. Salinas, Olfactory sensory neurons mediate ultrarapid antiviral immune responses in a TrkA-dependent manner, Proc. Natl. Acad. Sci. 116 (2019) 12428-12436. doi:10.1073/pnas.1900083116.

[101] G. Chevalier, E. Suberbielle, C. Monnet, V. Duplan, G. Martin-Blondel, F. Farrugia, G. Le Masson, R. Liblau, D. Gonzalez-Dunia, Neurons are MHC Class I-dependent targets for CD8 T cells upon neurotropic viral infection, PLoS 
Pathog. 7 (2011) e1002393. doi:10.1371/journal.ppat.1002393.

826

827

828

829

830

831

832

833

834

835

836

837

838

839

840

841

842

843

844

845

846

847

848

[102] D.D. Pinschewer, M. Schedensack, A. Bergthaler, E. Horvath, W. Brück, M. Löhning, D. Merkler, T cells can mediate viral clearance from ependyma but not from brain parenchyma in a major histocompatibility class I- and perforinindependent manner, Brain. 133 (2010) 1054-1066. doi:10.1093/brain/awq028.

[103] T. Korn, A. Kallies, T cell responses in the central nervous system, Nat. Rev. Immunol. 17 (2017) 179-194. doi:10.1038/nri.2016.144.

[104] U. Fischer, J.M. Dijkstra, B. Köllner, I. Kiryu, E.O. Koppang, I. Hordvik, Y. Sawamoto, M. Ototake, The ontogeny of MHC class I expression in rainbow trout (Oncorhynchus mykiss), Fish Shellfish Immunol. 18 (2005) 49-60. doi:10.1016/J.FSI.2004.05.006.

[105] F.R. Carbone, Tissue-resident memory T cells and fixed immune surveillance in nonlymphoid organs, J. Immunol. 195 (2015) 17-22. doi:10.4049/jimmunol.1500515.

[106] Y. Liu, C. Ma, N. Zhang, Tissue-specific control of tissue-resident memory T cells., Crit. Rev. Immunol. 38 (2018) 79-103. doi:10.1615/CritRevImmunol.2018025653.

[107] A.W. Ho, T.S. Kupper, T cells and the skin: from protective immunity to inflammatory skin disorders, Nat. Rev. Immunol. (2019). doi:10.1038/s41577019-0162-3.

[108] M.M. Wilk, K.H.G. Mills, CD4 Trm cells following infection and immunization: implications for more effective vaccine design, Front. Immunol. 9 (2018) 1860. doi:10.3389/fimmu.2018.01860.

[109] J.H.W.M. Rombout, L. Abelli, S. Picchietti, G. Scapigliati, V. Kiron, Teleost 

intestinal immunology, Fish Shellfish Immunol. 31 (2011) 616-626. doi:10.1016/j.fsi.2010.09.001.

[110] G. Scapigliati, Functional aspects of fish lymphocytes., Dev. Comp. Immunol. 41 (2013) 200-8. doi:10.1016/j.dci.2013.05.012.

[111] G. Scapigliati, A.M. Fausto, S. Picchietti, Fish lymphocytes: An evolutionary equivalent of mammalian innate-like lymphocytes?, Front. Immunol. 9 (2018) 971. doi:10.3389/fimmu.2018.00971.

[112] X.-H. Song, J. Tang, T.-T. Gao, X.-F. Xu, H.-X. Yang, K. Wu, C.-G. Yang, Z.Q. Cheng, B.-Y. Sun, Interleukin-12 receptor $\beta 2$ from grass carp: Molecular characterization and its involvement in Aeromonas hydrophila-induced intestinal inflammation, Fish Shellfish Immunol. $87 \quad$ (2019) 226-234. doi:10.1016/j.fsi.2019.01.016.

\section{Figure legends}

Fig. 1. Direct administration methods to mucosal organs. Percutaneous administration by stamp injection (A), per-gill administration (B), nasal immunisation (C) and anal intubation (D).

Fig. 2. Schematic diagram of a hypothesized mechanism in which cell-mediated immunity is elicited by mucosal immunisation with an inactivated virus, as based on a previous study [73]. Fish were anally intubated with inactivated virus (1). Dendritic cells in mucosal tissue ingest viral antigens and cross-present them on MHC class I (2). CTLs are clonally expanded in mucosal tissue following stimulation mediated by DC cells (3). 
873 CTLs circulate in the bloodstream and migrate into virus-infected organs (4). CTLs 874 recognize virally-infected cells in an MHC-restricted manner and induce lysis via 875 granzyme and perforin (5).

876

877 Fig. 3. Technique to investigate in vivo local immune responses using transparent fish 878 fins. (A) Visualization of fluorescent beads injected into fin membranes under ultraviolet 879 light. (B) Accumulation of leukocytes at the site of zymosan injection. PBS (left panel) 880 or $500 \mu \mathrm{g}$ zymosan (right panel) was administered into the fin. Arrow indicates infiltrated 881 leukocytes showing white aggregation. (C) Reduction of NBT in the fin following 882 zymosan administration, as observed under visible light at $24 \mathrm{~h}$ after administration of 883 0.2\% NBT with $100 \mu$ g (left) or without (right) zymosan. Note the change in color, since

884 NBT is a tetrazolium salt that is converted to a deep purple, water-insoluble formazan 885 product upon reduction by superoxide derived from leukocytes. 
Table 1 The methods of mucosal immunisation in teleost fish

\begin{tabular}{|c|c|c|c|c|}
\hline Mucosal vaccinations & Methods & Main target organs & Fish species & References \\
\hline \multirow[t]{6}{*}{ Immersion } & dip & skin, gill & many fishes & Reviewed in Nakanishi and Ototake 1997[33] \\
\hline & & & & Munang'andu et al., 2015[34] \\
\hline & hyperosmotic dip & skin, gill & flounder, common car & Huising et al., 2003[41], Gao et al., 2015[42],2016[43] \\
\hline & & & sockeye salmon & Antipa et al., 1980[40] \\
\hline & frequency sonophoresis & skin, gill & raibow trout & Cobo et al., 2014[44], 2015[45] \\
\hline & spray & skin & salmon, tilapia & Gould et al., 1978[38], Noraini et al., 2013[39] \\
\hline Immersion and punch & $\begin{array}{l}\text { immersion and punch using multiple } \\
\text { puncture instrument (stamp method) }\end{array}$ & skin & rainbow trout & Nakanishi et al., 2002[49] \\
\hline \multirow[t]{4}{*}{ Oral } & feeding (mix with food) & \multirow{2}{*}{\multicolumn{2}{|c|}{ stomach, intestine (gut) many fishes }} & Reviewed in Mutoloki et al., 2015[52] \\
\hline & & & & Embregts and Forlenza 2016[53] \\
\hline & intubation & \multirow{2}{*}{\multicolumn{2}{|c|}{$\begin{array}{l}\text { stomach , intestine (gut) ginbuna crucian carp } \\
\text { eel }\end{array}$}} & Sato et al., 2010[92] \\
\hline & & & & Esteve-Gassent et al., 2004[72] \\
\hline \multirow[t]{7}{*}{ Anal } & intubation & posterior intestine & ginbuna crucian carp & Tajimi et al., 2019[73] \\
\hline & & & common carp & Rombout et al., 1986[71], Sato et al., 2005[93] \\
\hline & & & eel & Esteve-Gassent et al., 2004[53] \\
\hline & & & african catfish & Vervarcke et al., 2005[85] \\
\hline & & & barramundi & Crosbie et al., 2004[86] \\
\hline & & & rainbow trout & Makesh et al., 2015[88] \\
\hline & & & grass carp & Song et al., 2019[112] \\
\hline Gill & direct exposure & gill & ginbuna crucian carp & Somamoto et al., 2015[74] \\
\hline Nasal & direct exposure & nasal cavity & rainbow trout & $\begin{array}{l}\text { Tacchi et al., 2014[27], Salinas et al., 2015[76], } \\
\text { Sepahi et al., } 2016 \text { [29], Magadan et al., 2019[90] } \\
\text { Sepahi et al., 2019[100] }\end{array}$ \\
\hline
\end{tabular}



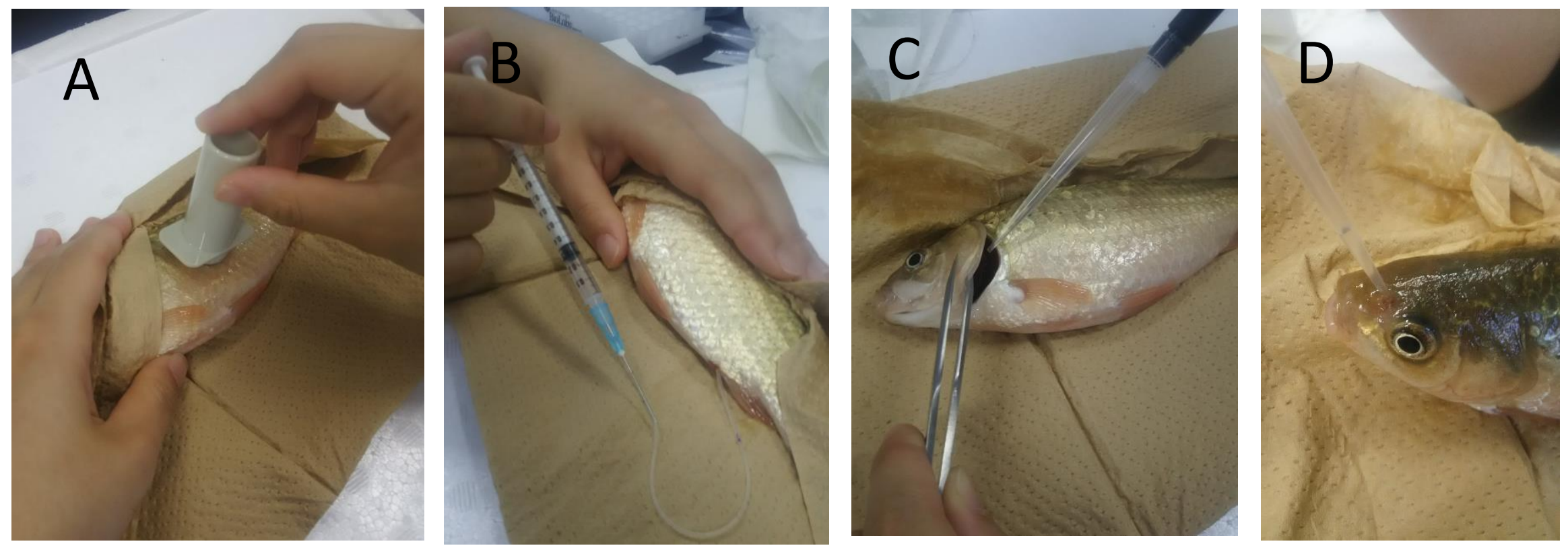

Fig.1 


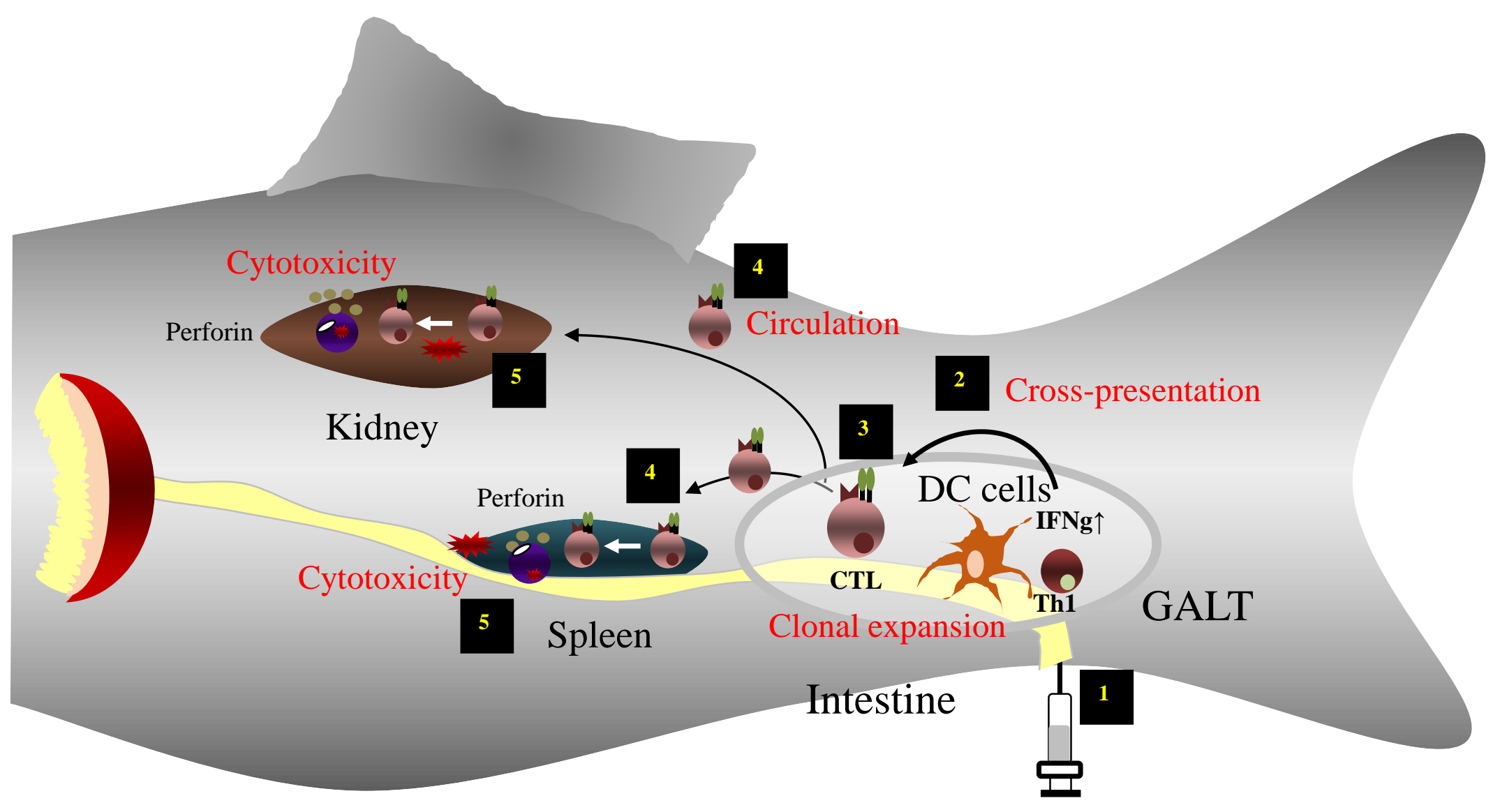

Fig. 2 
A

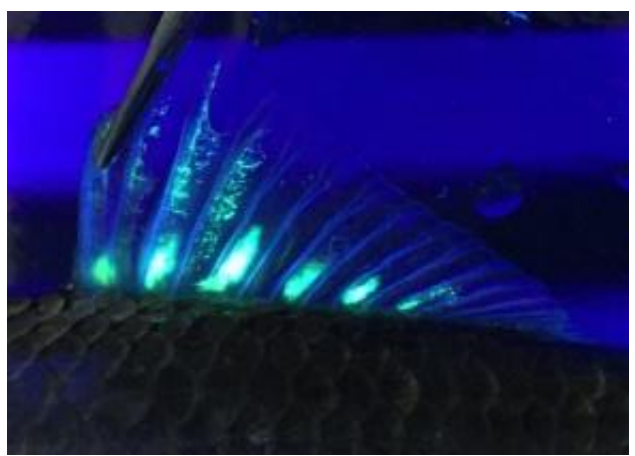

B
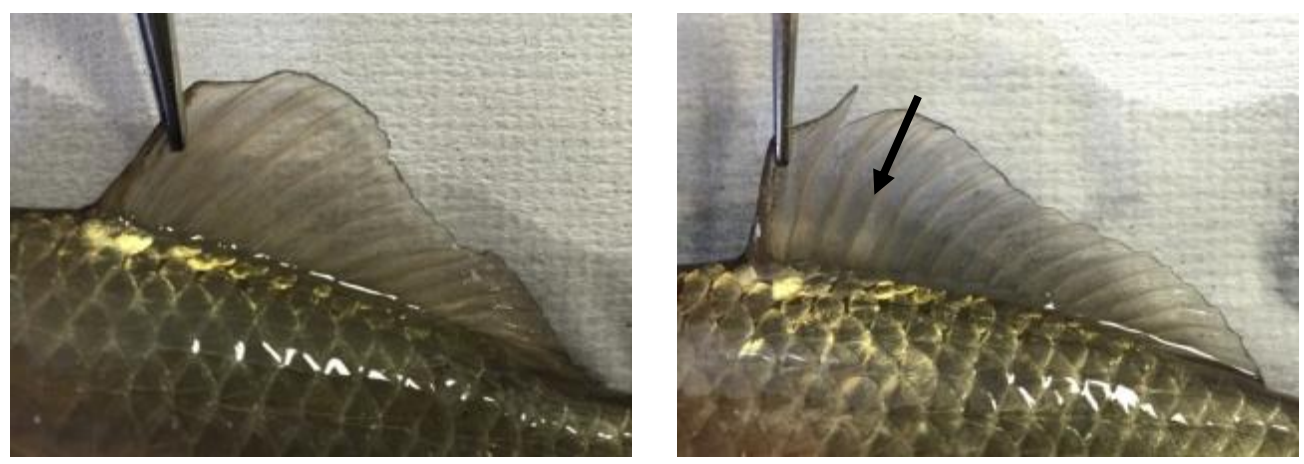

C
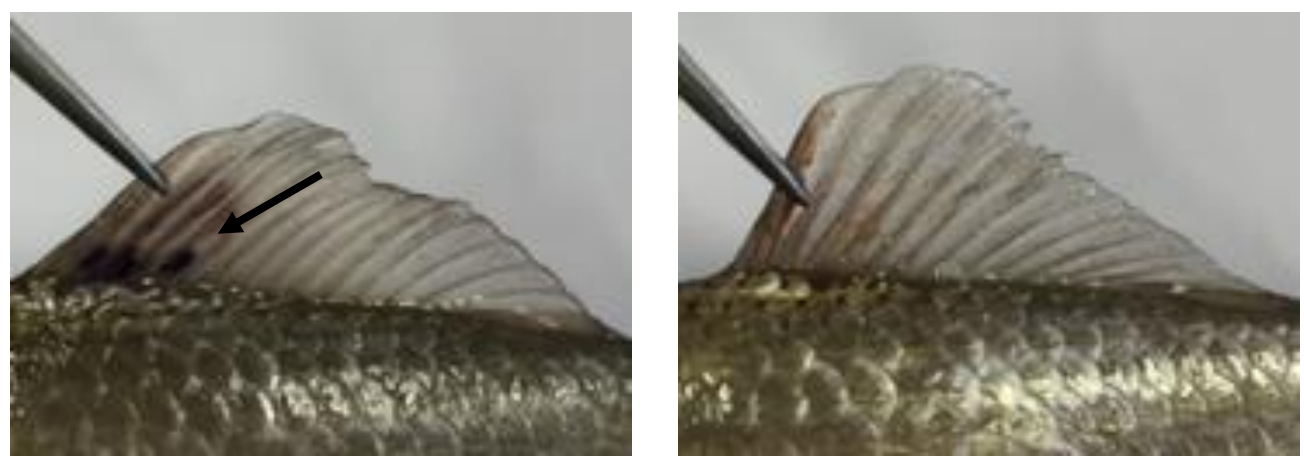

Fig.3 